\title{
NOTES ON THE OCCURRENCE OF SOME POORLY KNOWN DECAPODA (CRUSTACEA) IN THE SOUTHERN NORTH SEA
}

\author{
by
}

\author{
J. P. H. M. ADEMA
}

Rijksmuseum van Natuurlijke Historie, Leiden, The Netherlands

\author{
F. CREUTZBERG \& G. J. VAN NOORT
}

Netherlands Institute for Sea Research, Texel, The Netherlands

With 9 text-figures, 6 tables, 5 maps

\section{INTRODUCTION}

Since April 1972 an ecological trawl-survey programme has been undertaken by the Netherlands Institute for Sea Research (NIOZ), Texel, in the southern North Sea with the R. V. "Aurelia". The main object is to obtain information on distribution, density, biomass and fluctuations of crawling or swimming demersal (epibenthic) fauna such as small fishes, shrimps, prawns, crabs, asteroids, ophiuroids and some gastropods, for the evaluation of the role of these carnivores in the benthic ecosystem of the southern North Sea. Sedimentological aspects of the area are described by Creutzberg \& Postma (1979). Within the context of the present paper the most important feature is the mesh of $5 \times 5 \mathrm{~mm}^{2}$ of the cod end of the $51 / 2 \mathrm{~m}$ beam-trawl used and the extensive area of $5000-10,000 \mathrm{~m}^{2}$ covered during each haul. These exceptional circumstances resulted into faunistically interesting catches which gave rise to a cooperation with taxonomic specialists of the Rijksmuseum van Natuurlijke Historie (RMNH), Leiden.

The present paper deals with decapod crustaceans, collected during "Aurelia" -cruises, which are considered to be scarce or rare in the southern North Sea, completed with data from bottom-samples and other sources. The species in question are: Pandalina brevirostris, Spirontocaris lilljeborgii, Alpheus macrocheles, Pontophilus spinosus, Pontophilus bispinosus, Galathea dispersa, Ebalia tuberosa, Ebalia tumefacta, Ebalia cranchii, Atelecyclus rotundatus, Monodaeus couchii, Callianassa subterranea, Callianassa tyrrhena, Upogebia stellata and Upogebia deltaura.

Of the genus Macropodia a number of specimens have been collected, which partly were identified as $M$. linaresi. Other specimens, however, represent one or two new species. On Macropodia in the southern North Sea a seperate paper will be published (Van Noort \& Adema, in preparation).

Family Pandalidae Haworth, 1825

Pandalina brevirostris (Rathke, 1837)

(table 1)

Pandalina brevirostris; Holthuis, 1950: 33, fig. 19. Heerebout, 1974: 79, fig. 5. Van Leeuwen, 1975: 17, figs. 30, 32, 34, 35. Holthuis \& Heerebout, 1976: 10, 27, fig. 15. Van Noort, Van Leeuwen \& Creutzberg, 1979a: 10;1979c: 10, 48; 1979d: 10. Van Noort \& Creutzberg, 1981: 9, 48. 
TABLE 1

Distribution of Pandalina brevirostris in the southern North Sea

\begin{tabular}{|c|c|c|c|}
\hline Date & position & Station & number per $1000 \mathrm{~m}^{2}$ \\
\hline 3.v. 1972 & $52^{\circ} 31^{\prime} \mathrm{N} \quad 02^{\circ} 46^{\prime} \mathrm{E}$ & 94 & 2.6 \\
\hline $17 . x \cdot 1972$ & $53^{\circ} 35^{\prime} \mathrm{N} 04^{\circ} 29^{\prime} \mathrm{E}$ & 179 & 18 \\
\hline $17 . x .1972$ & $53^{\circ} 43^{\prime} \mathrm{N} 04^{\circ} 17^{\prime} \mathrm{E}$ & 180 & 36 \\
\hline $17 . x .1972$ & $54^{\circ} 06^{\prime} \mathrm{N} 04^{\circ} 00^{\prime} \mathrm{E}$ & 182 & 1.0 \\
\hline $17 . \times .1972$ & $54^{\circ} 25^{\prime} \mathrm{N} \quad 03^{\circ} 30^{\prime} \mathrm{E}$ & 185 & 0.7 \\
\hline $18 . x \cdot 1972$ & $54^{\circ} 30^{\prime} \mathrm{N} \quad 03^{\circ} 20^{\prime} \mathrm{E}$ & 186 & 0.2 \\
\hline $18 . x \cdot 1972$ & $54^{\circ} 08^{\prime} \mathrm{N} \quad 02^{\circ} 27^{\prime} \mathrm{E}$ & 192 & 2.7 \\
\hline $18 . x \cdot 1972$ & $54^{\circ} 00^{\prime} \mathrm{N} \quad 02^{\circ} 30^{\prime} \mathrm{E}$ & 193 & 0.6 \\
\hline $19 . x .1972$ & $53^{\circ} 08^{\prime} \mathrm{N} \quad 04^{\circ} 00^{\prime} \mathrm{E}$ & 201 & 3.6 \\
\hline $24 . x \cdot 1972$ & $52^{\circ} 20^{\prime} \mathrm{N} 03^{\circ} 23^{\prime} \mathrm{E}$ & 209 & 0.5 \\
\hline $25 . x .1972$ & $52^{\circ} 48^{\prime} \mathrm{N} 02^{\circ} 47^{\prime} \mathrm{E}$ & 211 & 9.0 \\
\hline $25 . x .1972$ & $52^{\circ} 46^{\prime} \mathrm{N} \quad 02^{\circ} 31^{\prime} \mathrm{E}$ & 212 & 129 \\
\hline $25 . x .1972$ & $52^{\circ} 39^{\prime} \mathrm{N} 02^{\circ} 30^{\prime} \mathrm{E}$ & 213 & 22.7 \\
\hline $25 . x \cdot 1972$ & $52^{\circ} 36^{\prime} \mathrm{N} 02^{\circ} 46^{\prime} \mathrm{E}$ & 214 & 2.9 \\
\hline $25 . x .1972$ & $52^{\circ} 32^{\prime} \mathrm{N} 03^{\circ} 30^{\prime} \mathrm{E}$ & 216 & 0.2 \\
\hline $30 . x \cdot 1972$ & $53^{\circ} 18^{\prime} \mathrm{N} \quad 03^{\circ} 49^{\prime} \mathrm{E}$ & 228 & 35.7 \\
\hline $31 . x .1972$ & $53^{\circ} 18^{\prime} \mathrm{N} \quad 02^{\circ} 48^{\prime} \mathrm{E}$ & 232 & 1.8 \\
\hline $31 . x \cdot 1972$ & $52^{\circ} 15^{\prime} \mathrm{N} \quad 02^{\circ} 35^{\prime} \mathrm{E}$ & 235 & 6.8 \\
\hline $31 . x \cdot 1972$ & $52^{\circ} 53^{\prime} \mathrm{N} \quad 02^{\circ} 47^{\prime} \mathrm{E}$ & 236 & 2.8 \\
\hline $31 . x .1972$ & $53^{\circ} 00^{\prime} \mathrm{N} 03^{\circ} 10^{\prime} \mathrm{E}$ & 238 & 2.1 \\
\hline 30.i. 1973 & $54^{\circ} 29^{\prime} \mathrm{N} 03^{\circ} 37^{\prime \prime} \mathrm{E}$ & 252 & 7.2 \\
\hline 31.i. 1973 & $54^{\circ} 06^{\prime} \mathrm{N} \quad 02^{\circ} 32^{\prime} \mathrm{E}$ & 260 & 0.4 \\
\hline 1.ii. 1973 & $53^{\circ} 19^{\prime} \mathrm{N} 03^{\circ} 51^{\prime} \mathrm{E}$ & 273 & 1.2 \\
\hline 6. ii. 1973 & $53^{\circ} 11^{\prime} \mathrm{N} 03^{\circ} 14^{\prime} \mathrm{E}$ & 283 & 38.4 \\
\hline 8.ii. 1973 & $52^{\circ} 36^{\prime} \mathrm{N} 04^{\circ} 17^{\prime} \mathrm{E}$ & 286 & 2.0 \\
\hline $14 . x \cdot 1974$ & $53^{\circ} 18^{\prime} \mathrm{N} \quad 03^{\circ} 48^{\prime} \mathrm{E}$ & 293 & 0.3 \\
\hline $14 . x .1974$ & $53^{\circ} 22^{\prime} \mathrm{N} \quad 03^{\circ} 41^{\prime} \mathrm{E}$ & 294 & 3.6 \\
\hline $15 . \times .1974$ & $54^{\circ} 43^{\prime} \mathrm{N} 00^{\circ} 06^{\prime} \mathrm{W}$ & 296 & 0.1 \\
\hline $15 . \times .1974$ & $54^{\circ} 57^{\prime} \mathrm{N} 00^{\circ} 26^{\prime} \mathrm{W}$ & 298 & 3.6 \\
\hline $15 . \times .1974$ & $55^{\circ} 05^{\prime} \mathrm{N} 00^{\circ} 35^{\prime} \mathrm{W}$ & 299 & 0.6 \\
\hline $17 . x \cdot 1974$ & $55^{\circ} 26^{\prime} \mathrm{N} 00^{\circ} 29^{\prime} \mathrm{E}$ & 305 & 1.1 \\
\hline 17.x. 1974 & $55^{\circ} 14^{\prime} \mathrm{N} \quad 00^{\circ} 42^{\prime} \mathrm{E}$ & 306 & 0.5 \\
\hline 17.x. 1974 & $54^{\circ} 55^{\prime} \mathrm{N} 01^{\circ} 21^{\prime} \mathrm{E}$ & 309 & 0.3 \\
\hline 17.x. 1974 & $54^{\circ} 45^{\prime} \mathrm{N} \quad 01^{\circ} 45^{\prime} \mathrm{E}$ & 310 & 1.1 \\
\hline $18 . \times 1974$ & $53^{\circ} 36^{\prime} \mathrm{N} \quad 04^{\circ} 25^{\prime} \mathrm{E}$ & 323 & 2.7 \\
\hline
\end{tabular}


According to Holthuis (1950) Pandalina brevirostris (Rathke) is known from the following localities in the southern North Sea: Helgoland, Margate, the Deepwater-Channel and the Dover Strait. The species should be rather scarce in the southern North Sea; it has one time been found 20 miles off the coast of Walcheren, Zeeland, approximately at $51^{\circ} 31^{\prime} \mathrm{N} 03^{\circ} 10^{\prime} \mathrm{E}$ (Heerebout, 1974; Holthuis \& Heerebout, 1976).

The species however, has frequently been found in the southern North Sea during the "Aurelia"-cruises; the results of the first five cruises are listed in table 1 (after Van Leeuwen, 1975; Van Noort, Van Leeuwen \& Creutzberg, 1979a, c \& d; Van Noort \& Creutzberg, 1981).

On 27.ix.1980 a single specimen of $P$. brevirostris was collected in the Oosterschelde near Flauwers, on the island of Schouwen, province of Zeeland, the Netherlands (leg. J. C. Post). This appeared to be the first record of this species within the Dutch territorial waters. The specimen forms part of the collection of the Leiden Museum.

Family Hippolytidae Bate, 1888

Spirontocaris lilljeborgii (Danielssen, 1859)

$$
\text { (fig. 1) }
$$

Spirontocaris lilljeborgii; Holthuis, 1950: 43, fig. 14

One specimen of Spirontocaris lilljeborgii (Danielssen) was collected on 9.x.1975 at $53^{\circ} 00^{\prime} \mathrm{N} 04^{\circ} 37^{\prime} \mathrm{E}$ (Sta. 352), near the south-west coast of the island of Texel. This is the first record of this species for the Netherlands. According to Holthuis (1950) the species could be expected in Dutch waters.

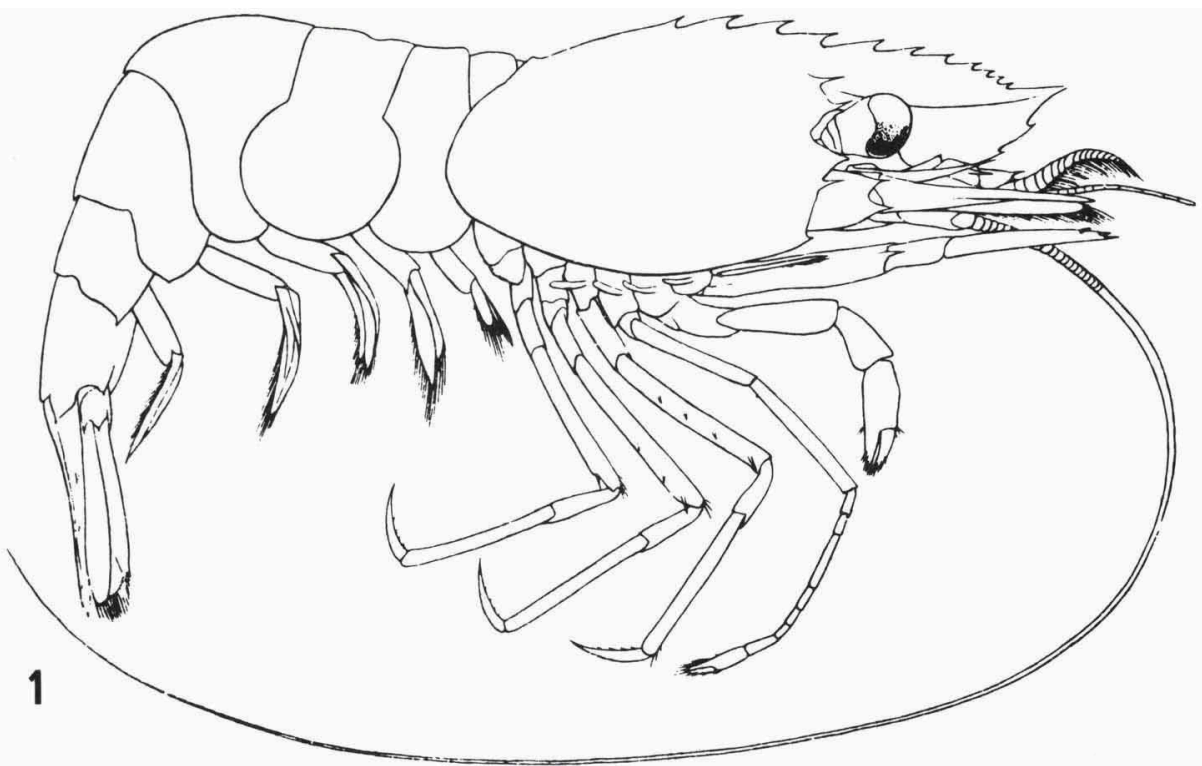

Fig. 1. Spirontocaris lilljeborgii, length $62 \mathrm{~mm}$ (after Holthuis, 1950). 
Alpheus macrocheles; Smaldon, 1979: 48, fig. 16.

Four specimens of Alpheus macrocheles (Hailstone) were collected during the "Aurelia"'-cruises; these are the first records of this species for the entire North Sea. The species is known from the Channel; in Great Britain it is recorded as far as Portland, at the south-coast (Smaldon, 1979). The specimens were collected on 25.ii.1976 at $52^{\circ} 48^{\prime} \mathrm{N} 02^{\circ} 34^{\prime} \mathrm{E}$ (Sta. 411, $1 \mathrm{ex}$ ) and at $52^{\circ} 33^{\prime} \mathrm{N}$ $02^{\circ} 43^{\prime} \mathrm{E}$ (Sta. $413,3 \mathrm{ex}$.).

Family Crangonidae Haworth, 1825

Pontophilus spinosus (Leach, 1815)

Pontophilus spinosus; Holthuis, 1950: 83, fig. 28. Smaldon, 1979: 112, figs. 41d, 50.

During the "Aurelia"-cruises three specimens of Pontophilus spinosus (Leach) were collected in the southern North Sea: one specimen on 18.xi.1974 at $53^{\circ} 49.5^{\prime} \mathrm{N} 04^{\circ} 05^{\prime} \mathrm{E}$ (Sta. 325), the two others on $16 . x .1975$ at $53^{\circ} 35.5^{\prime} \mathrm{N}$ $03^{\circ} 10^{\prime} \mathrm{E}$ (Sta. 369) and $53^{\circ} 40^{\prime} \mathrm{N} 03^{\circ} 25^{\prime} \mathrm{E}$ (Sta. 370). The locality of Sta.325 is situated 45 miles north-west of the island of Texel; the species has not been recorded before from so close to the Dutch coast. In the southern North Sea $P$. spinosus is known from the coast of Northumberland, Great Yarmouth, the White Bank, the Dogger Bank and Helgoland (Holthuis, 1950); according to Smaldon (1979) the species has been found along all British coasts. The specimen of Sta. 325 forms part of the collection of the Leiden Museum, the two others are in the collection of the Netherlands Institute for Sea Research.

\section{Pontophilus bispinosus Hailstone, 1835}

(tables 2-4)

Pontophilus bispinosus; Holthuis, 1950: 84, figs. 29, 30. Van Leeuwen, 1975: 17, figs. 8, 30, 31, 32, 35. Van Noort, Van Leeuwen \& Creutzberg, 1979a: 10;1979b: 10; 1979c: 10. Van Noort \& Creutzberg, 1981: 9 .

According to Holthuis (1950) Pontophilus bispinosus Hailstone is known from the following localities in the southern North Sea: the Dogger Bank, Helgoland, Borkum, the Deep Hole, the Deepwater-Channel and from a locality $1 \frac{1 / 2}{2}$ mile north-west of the lightship "Terschellingerbank".

The species has frequently been found in the southern North Sea during the "Aurelia"'-cruises; the results of the first five cruises are listed in table 2 (after Van Leeuwen, 1975; Van Noort, Van Leeuwen \& Creutzberg, 1979a, b, c; Van Noort \& Creutzberg, 1981).

The collection of the Leiden Museum holds a few specimens collected in the southern North Sea (table 3) and also a few specimens from the stomaches of fishes caught in the same area (table 4). 
TABLE 2

Distribution of Pontophilus bispinosus in the southern North Sea

\begin{tabular}{|c|c|c|c|}
\hline Date & position & station & number per $10000 \mathrm{~m}^{2}$ \\
\hline 25.iv. 1972 & $54^{\circ} 30^{\prime} \mathrm{N} 02^{\circ} 32^{\prime} \mathrm{E}$ & 64 & 14 \\
\hline $25 . i v \cdot 1972$ & $54^{\circ} 28^{\prime} \mathrm{N} 02^{\circ} 23^{\prime} \mathrm{E}$ & 65 & 1 \\
\hline 26.iv. 9172 & $53^{\circ} 52^{\prime} \mathrm{N} 02^{\circ} 30^{\prime} \mathrm{E}$ & 69 & 13 \\
\hline 26.iv. 1972 & $53^{\circ} 18^{\prime} \mathrm{N} 02^{\circ} 28^{\prime} \mathrm{E}$ & 73 & 6 \\
\hline 28.iv. 1972 & $52^{\circ} 54^{\prime} \mathrm{N} 04^{\circ} 28^{\prime} \mathrm{E}$ & 82 & 0 \\
\hline 2.v. 1972 & $52^{\circ} 51^{\prime} \mathrm{N} \quad 03^{\circ} 42^{\prime} \mathrm{E}$ & 88 & 1 \\
\hline 4.v. 1972 & $52^{\circ} 34^{\prime} \mathrm{N} \quad 03^{\circ} 41^{\prime} \mathrm{E}$ & 102 & 144 \\
\hline 4.v. 1972 & $52^{\circ} 30^{\prime} \mathrm{N} \quad 03^{\circ} 18^{\prime} \mathrm{E}$ & 105 & 230 \\
\hline 28.vii. 1972 & $54^{\circ} 19^{\prime} \mathrm{N} 02^{\circ} 26^{\prime} \mathrm{E}$ & 127 & 3 \\
\hline 29.vii. 1972 & $53^{\circ} 22^{\prime} \mathrm{N} 02^{\circ} 46^{\prime} \mathrm{E}$ & 136 & 1 \\
\hline 17.x.1972 & $54^{\circ} 06^{\prime} \mathrm{N} 04^{\circ} 00^{\prime} \mathrm{E}$ & 182 & 3 \\
\hline 17.x. 1972 & $54^{\circ} 20^{\prime} \mathrm{N} 03^{\circ} 50^{\prime} \mathrm{E}$ & 184 & 10 \\
\hline $17 . x .1972$ & $54^{\circ} 25^{\prime} \mathrm{N} \quad 03^{\circ} 30^{\prime} \mathrm{E}$ & 185 & 15 \\
\hline $18 . x .1972$ & $54^{\circ} 08^{\prime} \mathrm{N} 02^{\circ} 27^{\prime} \mathrm{E}$ & 192 & 4 \\
\hline $18 . x .1972$ & $54^{\circ} 00^{\prime} \mathrm{N} 02^{\circ} 30^{\prime} \mathrm{E}$ & 193 & 4 \\
\hline 19.x. 1972 & $53^{\circ} 03^{\prime} \mathrm{E} 04^{\circ} 19^{\prime} \mathrm{E}$ & 202 & 12 \\
\hline $30 . x .1972$ & $53^{\circ} 18^{\prime} \mathrm{N} \quad 03^{\circ} 49^{\prime} \mathrm{E}$ & 228 & 81 \\
\hline $30 . x .1972$ & $53^{\circ} 26^{\prime} \mathrm{N} \quad 03^{\circ} 40^{\prime} \mathrm{E}$ & 229 & 3 \\
\hline 4.iii. 1976 & $52^{\circ} 50^{\prime} \mathrm{N} 03^{\circ} 57^{\prime} \mathrm{E}$ & 439 & 1 \\
\hline
\end{tabular}

TABLE 3

Pontophilus bispinosus collected in the southern North Sea (RMNH-collection)

$\begin{array}{llll}\text { Date } & \text { locality } & \text { leg. } & \text { RMNH-number } \\ 7 / 19 . x i 1.1950 & 51^{\circ} 39^{\prime} \mathrm{N} 02^{\circ} 34^{\prime} \mathrm{E} & \mathrm{NIOZ} & 21709 \\ \text { 10.iv.1952 } & 53^{\circ} 23^{\prime} \mathrm{N} 04^{\circ} 13^{\prime} \mathrm{E} & \mathrm{NIOZ} & 19282 \\ 12 . \mathrm{iv.1952} & \text { NW off the "Brandaris" } & \mathrm{NIOZ} & 19281 \\ & \text { (Tersche11ing) } & & \\ 19 . \mathrm{iv.1952} & 53^{\circ} 38^{\prime} \mathrm{N} 04^{\circ} 02^{\prime} \mathrm{E} & \mathrm{NIOZ} & 19280 \\ 26 . \mathrm{iv.1952} & 53^{\circ} 30^{\prime} \mathrm{N} 04^{\circ} 02^{\prime} \mathrm{E} & \mathrm{NIOZ} & 19273 / 4 \\ 19 . x i .1952 & 53^{\circ} 04^{\prime} \mathrm{N} 04^{\circ} 16^{\prime} \mathrm{E} & \mathrm{NIOZ} & 19278 \\ 16 . \mathrm{i} .1953 & \mathrm{NW} \text { off the "Brandaris" } & \mathrm{NIOZ} & 19276\end{array}$


TABLE 4

Pontophilus bispinosus from the stomachs of fishes

\begin{tabular}{|c|c|c|c|}
\hline Date & locality & species of fish & RMNH-number \\
\hline 26.iii.1949 & Deep Hole & Raja batis L., 1758 & 6160 \\
\hline 12.v. 1949 & "Westpunt" & R. clavata L., 1758 & 6161 \\
\hline 12.v. 1949 & "Westpunt" & R. montagui Fowler, 1910 & 6162 \\
\hline 14.v. 1949 & Buiten de Stenen & R. clavata L., 1758 & 6159 \\
\hline 14.v. 1949 & Buiten de Stenen & R. montagui Fowler, 1910 & 6163 \\
\hline 7.vi. 1949 & Buiten de Stenen & R. clavata L., 1758 & 6164 \\
\hline 16.vi. 1949 & off IJmuiden & Aspitrigla cuculus (L., 1758) & 6158 \\
\hline 2.iii.1950 & Deep Hole & R. batis L. 1758 & 6475 \\
\hline 7.xii.1951 & Buiten de Stenen & R. montagui Fowler, 1910 & 7885 \\
\hline \multirow[t]{2}{*}{ 26.iii.1956 } & $53^{\circ} 51^{\prime} \mathrm{N} 03^{\circ} 42^{\prime} \mathrm{E} \mathrm{à}$ & & \\
\hline & $53^{\circ} 42^{\prime} \mathrm{N} 03^{\circ} 52^{\prime} \mathrm{E}$ & Rhinonemus cimbrius (L., 176 & 6) 7886 \\
\hline
\end{tabular}

Family Galatheidae Dana, 1852

Galathea dispersa Bate, 1859

One specimen of Galathea dispersa Bate was collected on 9.x.1979 at $53^{\circ} 46.5^{\prime} \mathrm{N}$ $04^{\circ} 19.5^{\prime} \mathrm{E}$ (Sta. 532c) at a depth of 40 meters. This species has not been reported before from near the Dutch coast and was not mentioned by Holthuis (1950) and Holthuis \& Heerebout (1976) in their enumerations of Dutch Decapoda.

Family Leucosinde Samouelle, 1819

Genus Ebalia Leach, 1817

During the "Aurelia"'-cruises two species of Ebalia Leach were collected frequently: E. tumefacta (Montagu, 1808) and E. cranchii Leach, 1817, and one species only occasionally: E. tuberosa (Pennant, 1777). From earlier bottomfauna studies of the southern North Sea only few data are available (Davis, 1925; Hagmeier, 1925; Caspers, 1939). Some more information on Ebalia therefore, may be presented here.

For the identification of $E$. tumefacta and $E$. cranchii the respectively octogonal and rhomboid contours of the carapace were used (Christiansen, 1969). Further in $E$. tumefacta the carapace is usually slightly broader than long, whereas in $E$. chranchii the opposite is true, but nevertheless the width/length ratio shows an overlap if the sexes are not taken into account. If, however, the sexes are measured separately, the overlap does not longer interfere with the identification (Fig. 3). The width/length ratio of the males alone or of the females alone of the two species do not overlap. 
Ebalia tuberosa (Pennant, 1777)

(fig. 2; map 1)

Ebalia luberosa; Davis, 1925: 40 table c. Christiansen, 1969: 27, fig. 9. Holthuis \& Heerebout, 1976: 16, fig. 57.

Ebalia tuberosa (Pennant) is not very common in the central and southern North Sea. Davis (1925) mentioned two specimens collected near Flamborough Head and three specimens off the Suffolk coast. According to Christiansen (1969) E. tuberosa is known from the following localities in the central and southern North Sea: East coast of the British Isles; North Sea coast of France and Belgium and the southernmost part of the North Sea.

Wolff \& Sandee (1971) collected a specimen off the Walcheren coast (approximately at $51^{\circ} 29^{\prime} \mathrm{N} 03^{\circ} 10^{\prime} \mathrm{E}$ ) on $18 . x .1962$, but they identified it as E. tumefacta. A careful examination of this specimen (now in the RMNH-collection) revealed that it belongs to $E$. tuberosa. The specimen is a female, with a length of $13.0 \mathrm{~mm}$ and a breadth of $14.4 \mathrm{~mm}$.

During the "Aurelia"'-cruises $E$. tuberosa has been found on three localities in the southern North Sea in the Southern Bight and on three localities in Northumberland waters (map 1).

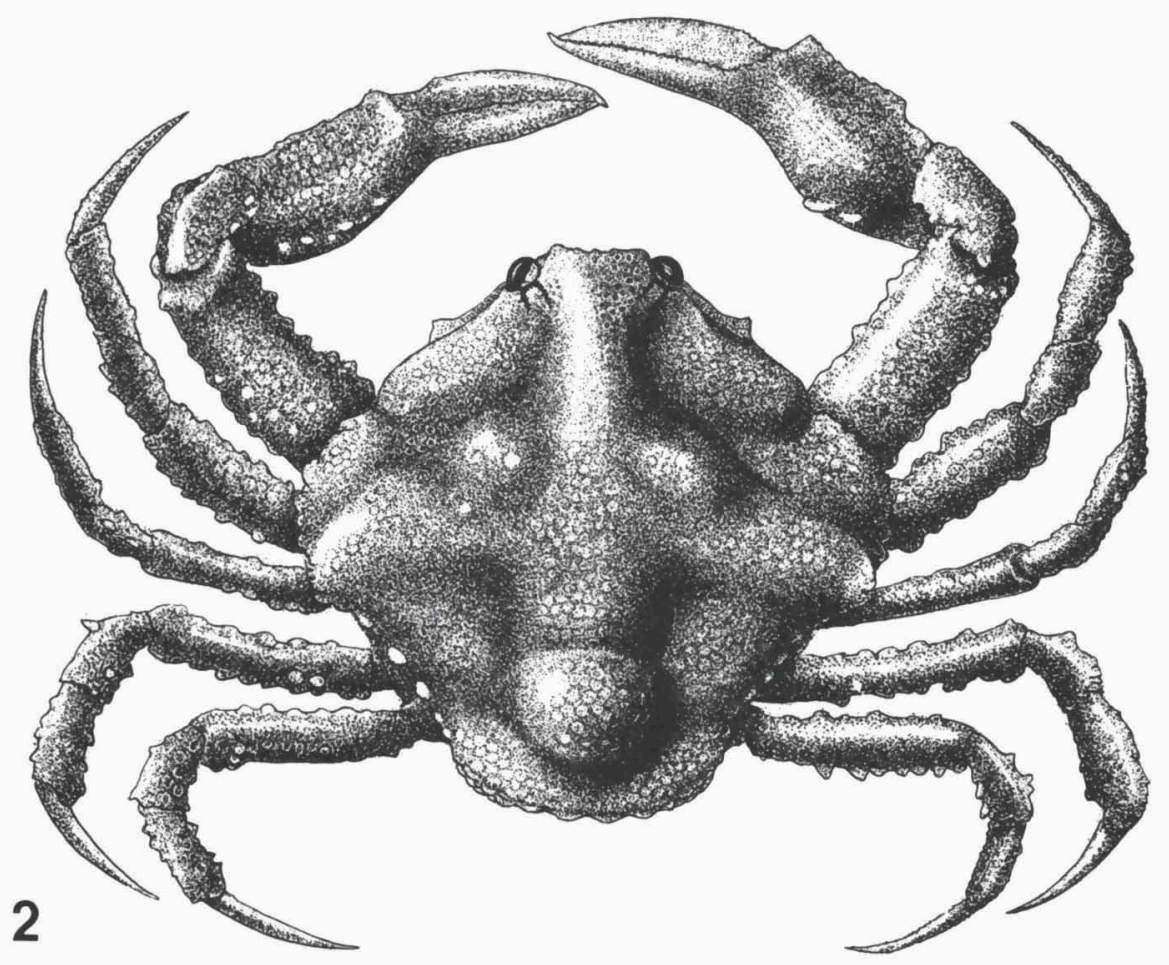

Fig. 2. Ebalia tuberosa, breadth $18 \mathrm{~mm}$ (P. van 't Zelfde, RMNH, del.). 


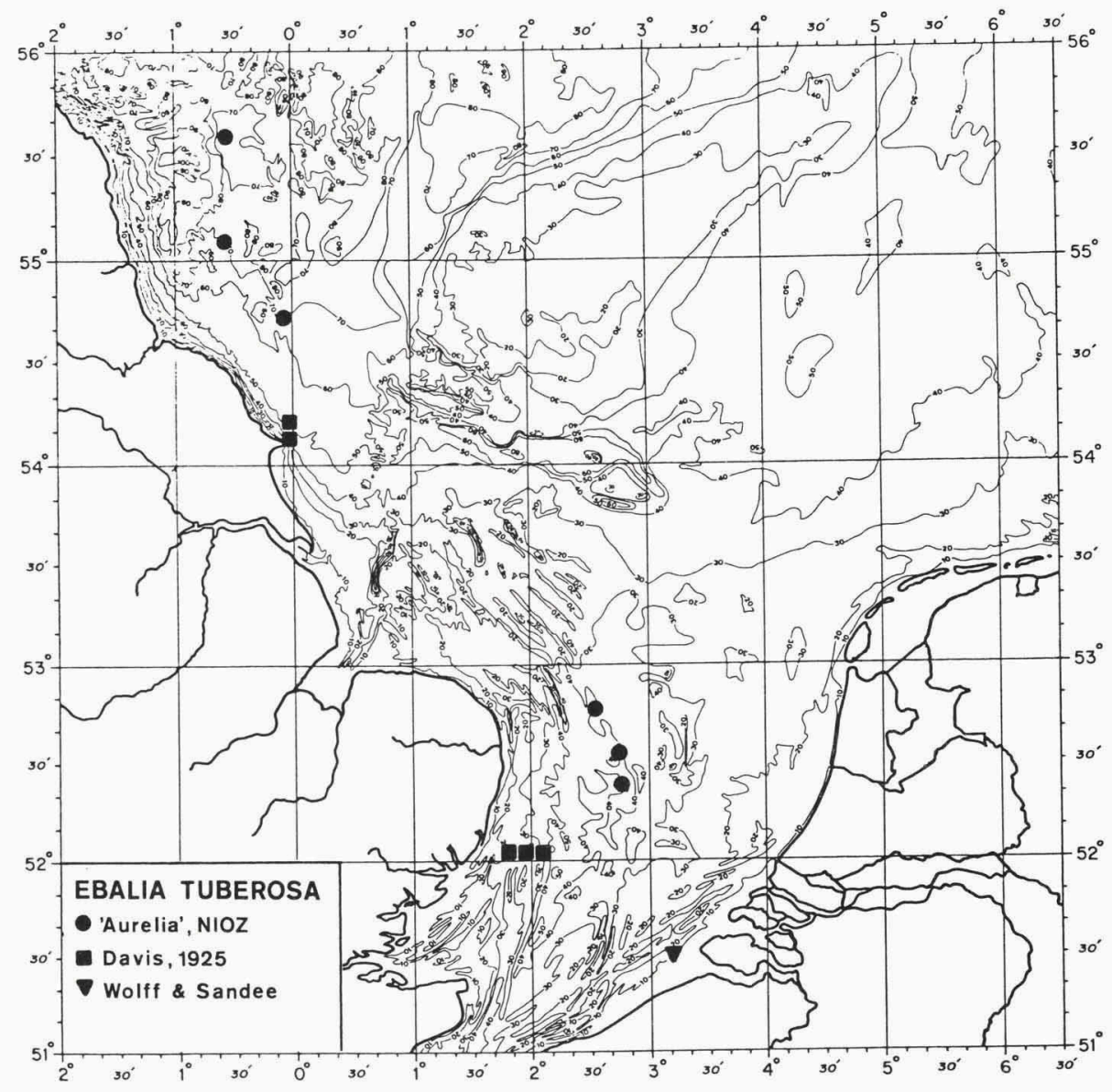

Map 1. Ebalia tuberosa in the southern North Sea.

Ebalia tumefacta (Montagu, 1808)

(fig. 3; map 2)

Ebalia tumefacta; Davis, 1925: 40 table c. Caspers, 1939: 44. Christiansen, 1969: 29, fig. 10.

In early bottom-fauna studies (Davis, 1925; Caspers, 1939) the species is scarcely mentioned. According to Christiansen (1969) Ebalia tumefacta (Montagu) is found on stony bottom, with pebbles, gravel, shell debris and sand, more seldom on sandy mud and clay. During the "Aurelia"'-cruises E. tumefacta has frequently been collected, mainly in the south-western part of the investigated area, where, indeed, sediments are coarser than in the north-eastern part (map 2). 

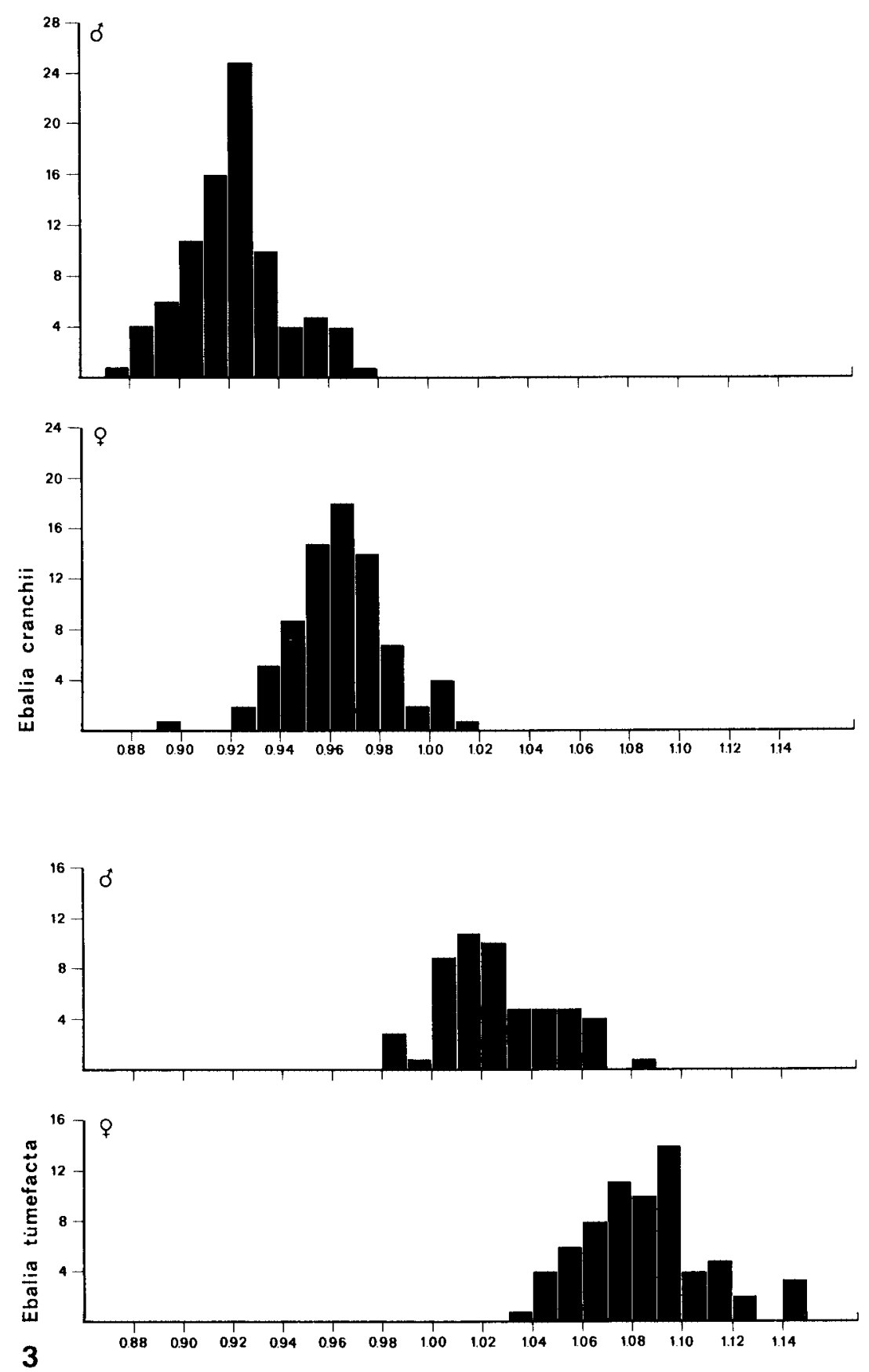

Fig. 3. Relative breadth (br/L) of the carapace of Ebalia cranchii and E. tumefacta; explanation see text. 
ZOOLOGISCHE BIJDRAGEN 28 (1982)

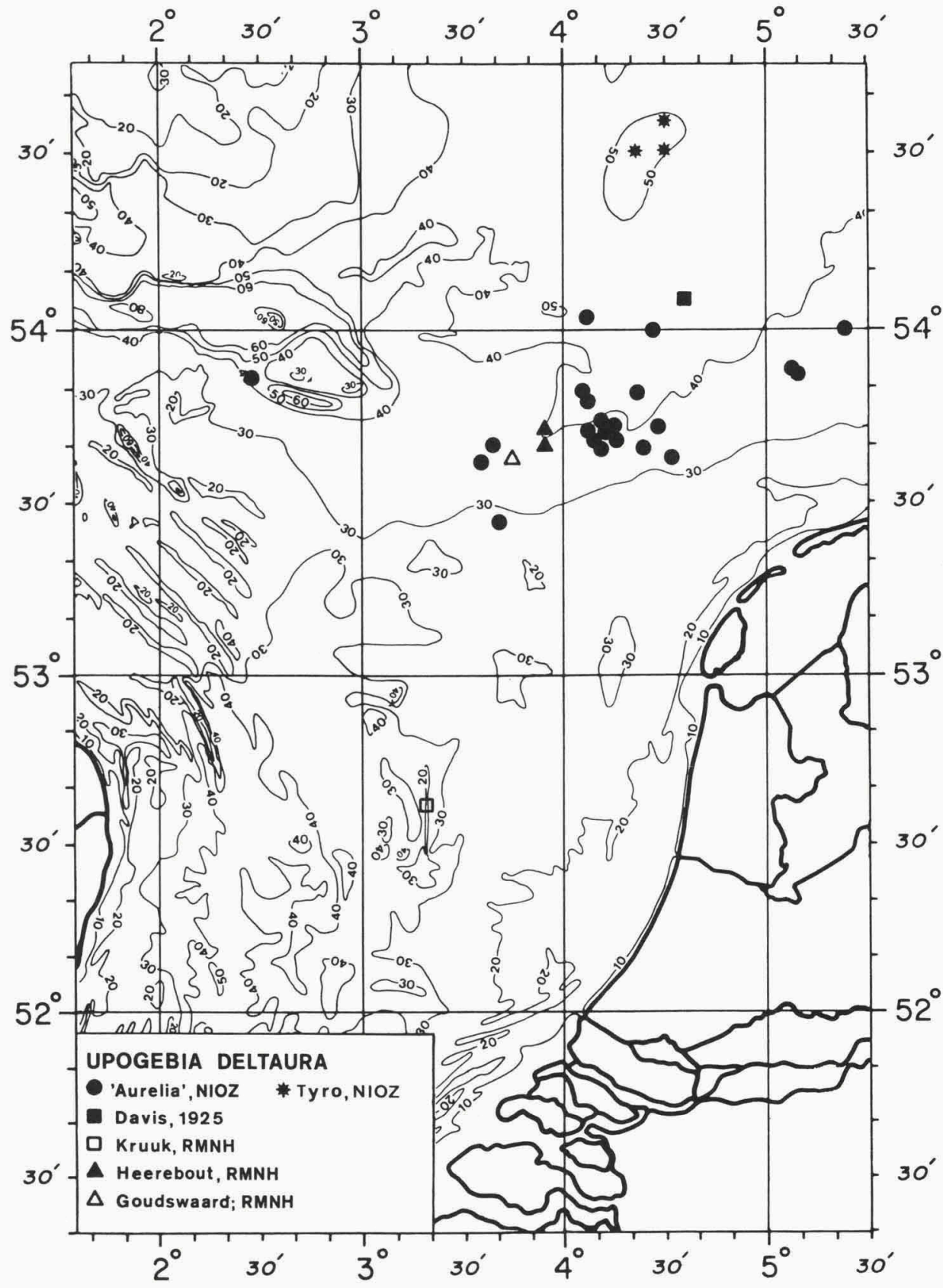

Map 2. Ebalia tumefacta in the southern North Sea. 
Ebalia cranchii Leach, 1817

(fig. 3; map 3)

Ebalia cranchii; Davis, 1925: 40. Hagmeier, 1925: 268. Caspers, 1939: 44, 70 tabel 13. Christiansen, 1969: 31, fig. 11. Holthuis \& Heerebout, 1976: 16, fig. 59 .

Ebalia cranchii Leach is recorded by Hagmeier (1925) and Caspers (1939) for the German Bight. According to Christiansen (1969) the distribution tends to be northerly of the Wadden Islands (central North Sea; see also Holthuis \& Heerebout, 1976). This distribution pattern may be in accordance with the occurrence of $E$. cranchii "on bottom with small stones, gravel and sand, but also found on bottom with mud" (Christiansen, 1969).

During the "Aurelia"-cruises the species appeared to be common especially in the north-eastern part of the investigated area, where sediments are fine to muddy, but also, southerly, partly overlapping the "E. tumefacta area" (map 3). $E$. tumefacta, however, seems to avoid areas with fine sediments.

This view on geographical separation of the two species does not cover the observations of Davis (1925). Davies does not mention E. cranchii at all, but found seven specimens of $E$. tumefacta along a traject from $53^{\circ} 47^{\prime} \mathrm{N} 03^{\circ} 40^{\prime} \mathrm{E}$ to $54^{\circ} 29^{\prime} \mathrm{N} 05^{\circ} 38^{\prime} \mathrm{E}$, right through the ' $E$. cranchii area'. In his summarizing table C, Davis classified $E$. tumefacta as an inhabitant of muddy sediments.

Family Atelecyclidae Ortmann, 1893

Atelecyclus rotundatus (Olivi, 1792)

(fig. 4 ; table 5)

Atelecyclus rotundatus; Leloup, 1941: 13, 1 map. Holthuis, 1950: 94. Christiansen, 1969: 37, map 7 Ingle, 1980: 103, fig. 46, pl. 14a.

Records of Atelecyclus rotundatus (Olivi) from the southern North Sea are rather scarce. The species has been recorded from the lightship West-Hinder, off the Belgian coast (Leloup, 1941) and from Yorkshire (Ingle, 1980). There is only one single doubtful record from the Netherlands: the collection of the Natuurhistorisch Museum, Rotterdam, holds one specimen of $A$. rotundatus with a lable: "between Vlieland and Terschelling, march 1930". Since in the same collection there is a specimen of Maja squinado (Herbst, 1788) (Brachyura, Majidae) and Palinurus elephas (Fabricius, 1787), with the same lable, it is very likely that the locality on the lable is incorrect (Holthuis, 1950). Christiansen (1969) only mentioned the record from the lightship West-Hinder; she reports the species from the northern North Sea.

During the "Aurelia"-cruises 11 specimens of $A$. rotundatus were collected in the southern North Sea, between 1972 and 1979 (table 5). On 8/9.ix.1980 16 specimens of the species were collected some 40 miles west off IJmuiden (NoordHolland) by mr. H. Strack of the Natuurhistorisch Museum, Rotterdam (table $5)$. 
ZOOLOGISCHE BIJDRAGEN 28 (1982)

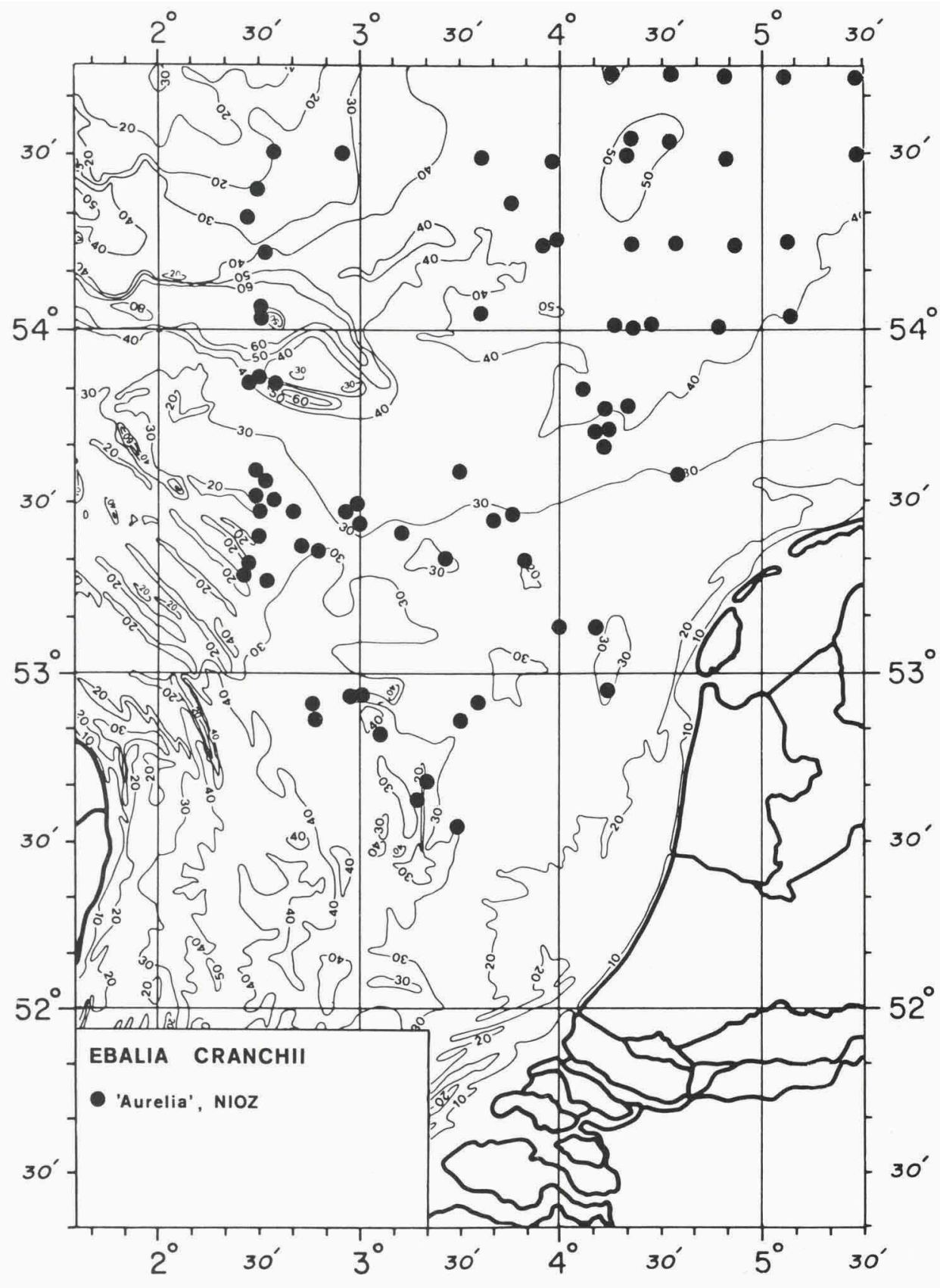

Map 3. Ebalia cranchii in the southern North Sea 


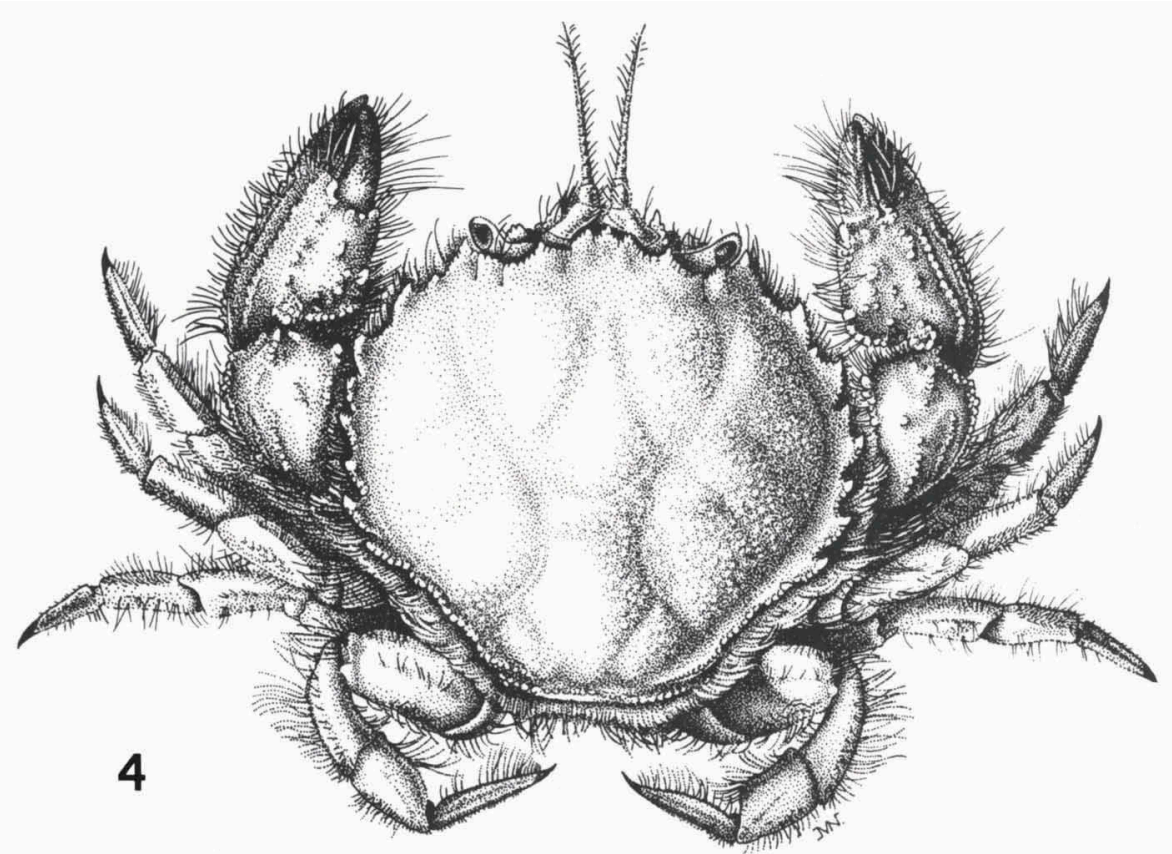

Fig. 4. Atelecyclus rotundatus $\sigma$, Sta. 509B, H. Breadth $20.3 \mathrm{~mm}$ (I. van Noortwijk, RMNH, del.).

TABLE 5

Distribution of Atelecyclus rotundatus in the southern North Sea

\begin{tabular}{|c|c|c|c|c|}
\hline Date & locality & station & number & collection \\
\hline $25 . x .1972$ & $52^{\circ} 46^{\prime} \mathrm{N} \quad 02^{\circ} 31^{\prime} \mathrm{E}$ & 212 & 1 & RMNH \\
\hline $15 . \times .1974$ & $54^{\circ} 57^{\prime} \mathrm{N} 00^{\circ} 26^{\prime} \mathrm{W}$ & 298 & 1 & NIOZ \\
\hline $15 . \times .1974$ & $55^{\circ} 29^{\prime} \mathrm{N} \quad 00^{\circ} 28^{\prime} \mathrm{W}$ & 301 & 3 & $\mathrm{RMONH} / \mathrm{NIOZ}$ \\
\hline 25.ii.1976 & $52^{\circ} 57^{\prime} \mathrm{N} 02^{\circ} 58^{\prime} \mathrm{E}$ & 409 & $1^{*}$ & RMNH \\
\hline 25.ii.1976 & $52^{\circ} 40^{\prime} \mathrm{N} \quad 02^{\circ} 39^{\prime} \mathrm{E}$ & 412 & $2^{*}$ & RMNH \\
\hline 20.ii.1979 & $53^{\circ} 45^{\prime} \mathrm{N} 04^{\circ} 18^{\prime} \mathrm{E}$ & $509 \mathrm{~L}$ & 1 & RMNH \\
\hline 20.ii.1979 & $53^{\circ} 45^{\prime} \mathrm{N} 04^{\circ} 17^{\prime} \mathrm{E}$ & $509 \mathrm{~B}, \mathrm{H}$ & $2^{*}$ & RMNH \\
\hline 8.ix. 1980 & $52^{\circ} 24^{\prime} \mathrm{N} \quad 03^{\circ} 15^{\prime} \mathrm{E}$ & -- & 2 & NMR 228 \\
\hline $8 . i x .1980$ & $52^{\circ} 32^{\prime} \mathrm{N} 02^{\circ} 45^{\prime} \mathrm{E}$ & -- & 8 & NMR 231 (6 exx.)/RMNH \\
\hline 9.ix. 1980 & $52^{\circ} 35^{\prime} \mathrm{N} \mathrm{O2} 2^{\circ} 45^{\prime} \mathrm{E}$ & - & 6 & NMR 235 \\
\hline
\end{tabular}

*: one ovigerous 9. 
Family Xanthidae MacLeay, 1838

Monodaeus couchii (Couch, 1851)

(fig. 5)

Monodaeus couchii; Ingle, 1980: 115, figs. 62, 63, pl. $20 \mathrm{~b}$.

One male specimen of Monodaeus couchii (Couch) was collected during the “Aurelia"'-cruises on 15.x.1974 at $54^{\circ} 57^{\prime} \mathrm{N} 02^{\circ} 25.6^{\prime} \mathrm{W}$ (Sta. 298, off the British coast near Newcastle). This is the first record of this species for the entire North Sea; the species has not been mentioned by Christiansen (1969). The most nearby locality where $M$. couchii has been found is the Plymouth area at the English Channel coast (Ingle, 1980).

$M$. couchii can be distinguished from Xantho pilipes. A. Milne Edwards, 1867, and $X$. incisus Leach, 1814 , by the densely setose dactylus of the walking legs, the pronounced antero-external angle of the third maxillipeds and the strongly tuberculated chelipeds (Ingle, 1980).

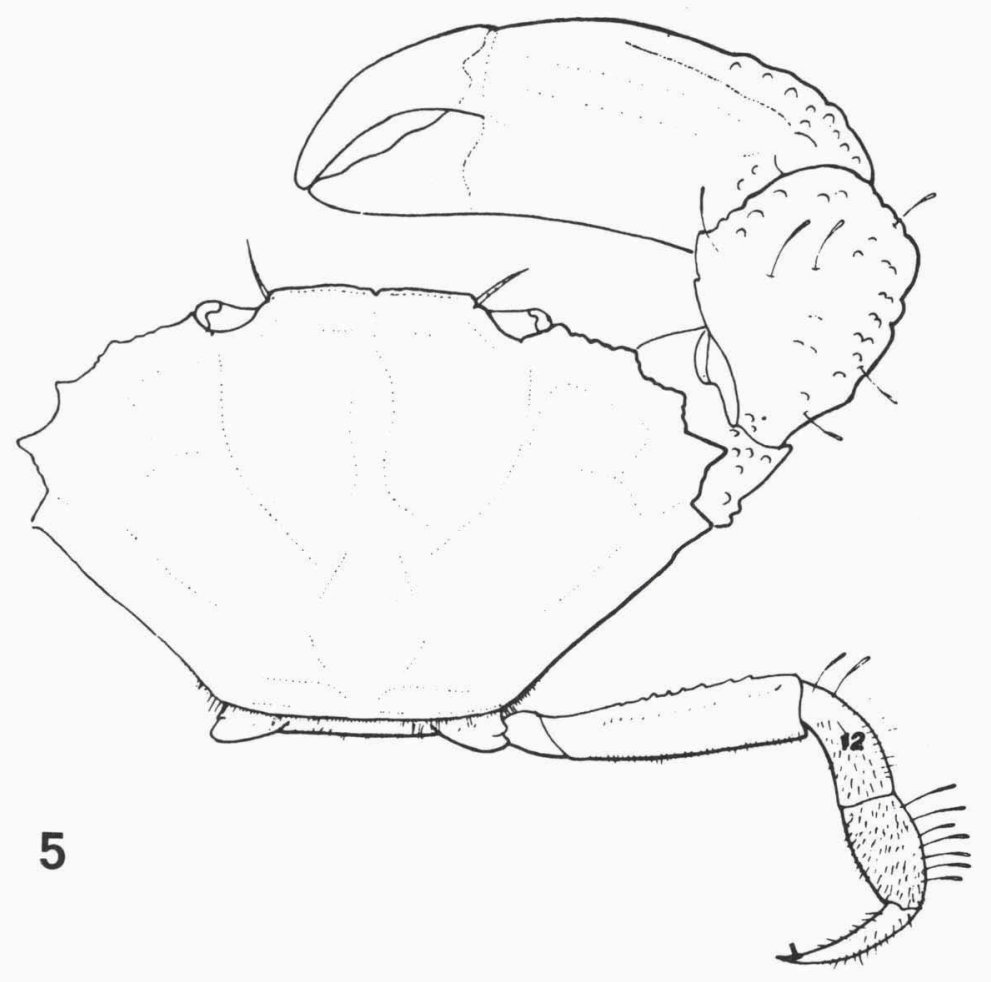

Fig. 5. Monodaeus couchii, $\sigma$, breadth $15 \mathrm{~mm}$, Plymouth (after Ingle, 1980). 
Family Callianassidae Bate, 1888

Genus Callianassa Leach, 1814

Holthuis (1950) and Holthuis \& Heerebout (1976) mentioned only one species of Callianassa Leach, 1814, when enumerating the Dutch Decapoda, viz. C. tyrrhena (Petagna, 1792). In off-shore waters north of Holland, however, C. subterranea (Montagu, 1808) seems to be the most common species. The two species can be identified as follows (after Saint-Laurent \& Božić, 1972):

1. Telson trapezium-shaped, toothed. Cornea small, placed in the middle of the dorsal surface of the eyestalk. Merus of the larger cheliped with a long pointed spine. Merus of the third maxilliped longer than broad; ischium of the third maxilliped longer than broad, with long spines

C. subterranea (figs. 6a-c)

- Telson rounded, without spinules. Cornea large, touching the outer edge of the dorsal surface of the eyestalk. Merus of the larger cheliped with a small, blunt spine. Merus of the third maxilliped much broader than long; ischium of the third maxilliped as long as broad, with small spines

C. tyrrhena (figs. 7a-c)

Callianassa subterranea (Montagu, 1808)

(fig. 6a-c; map 4)

Callianassa subterranea; Davis, 1925: 40. Lutze, 1938: 170, figs. 28-51. Caspers, 1939: 42, 70.

Saint Laurent \& Božić, 1972: 17, figs. 1, 9, 17, 28.

Callianassa tyrrhena; ?Van Noort, Van Leeuwen \& Creutzberg, 1979b: 10

Callianassa subterranea (Montagu) is found in the southern North Sea in areas with fine or muddy sediments. Davis (1925) collected six specimens in the Oyster Ground and three specimens in the Outer Silver Pit. Lutze (1938) summarized all bottom-sampler catches of $C$. subterranea made during the "Poseidon" and "Meteor"'-cruises in the years 1935-1937 and found high densities (ranging from 10 to 180 per $\mathrm{m}^{2}$ ) in the Oyster Ground, Outer Silver Pit and Markham's Hole. According to Caspers (1939) C. subterranea is very common in the Helgoland Channel in sandy mud. Pure sand seems to be avoided.

During the "Aurelia"'-cruises C. subterranea was seldom caught with the beamtrawl and in the beginning (June 1972; Sta. 117 \& 140) it most probably was erroneously identified as $C$. tyrrhena (Van Noort, Van Leeuwen \& Creutzberg, 1979b). When, however, a Van Veen bottom-sampler was used, it became clear that $C$. subterranea is very common in the silty and muddy areas of the Oyster Ground, Outer Silver Pit, Botney Cut and Markham's Hole (map 4). South of the latitude of $53^{\circ} 20^{\prime} \mathrm{N}$, on the other hand, $C$. subterranea is obviously rare. In the Southern Bight only a few data are known: 20/27.viii.1960, Brown Ridge, one specimen, leg. G. Kruuk (RMNH 16614); 12.ii. $198052^{\circ} 19^{\prime} 59^{\prime \prime} \mathrm{N} 03^{\circ} 10^{\prime} 40^{\prime \prime} \mathrm{E}$, three specimens, leg. M. Mulder (Collection BOEDE, Texel; map 4). 

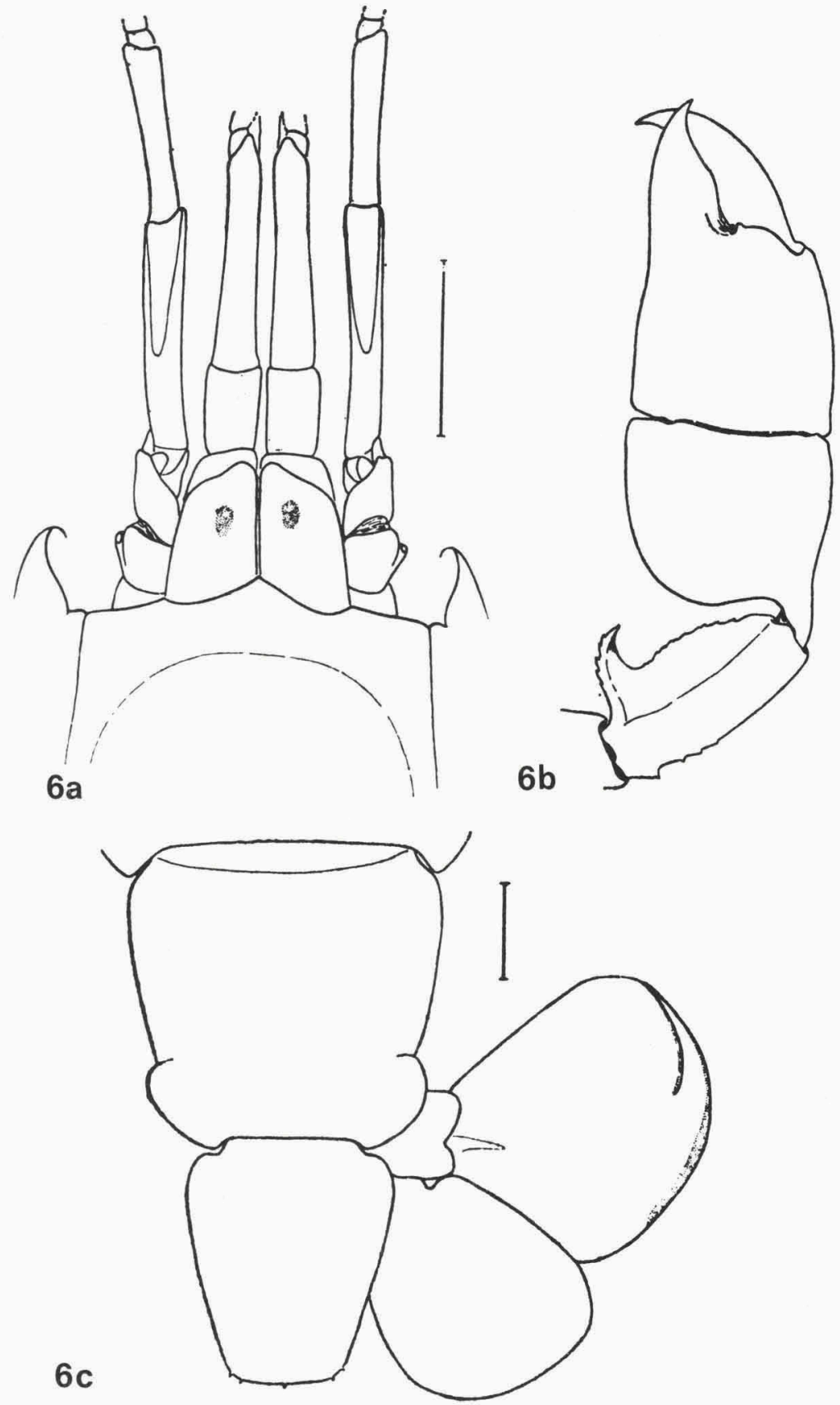

Fig. 6. Callianassa subterranea, \&, length $50 \mathrm{~mm}$, Plymouth (after Saint Laurent \& Božić, 1972). a, frontal region of the carapace, showing the eyes; $b$, larger cheliped; $c$, telson. 


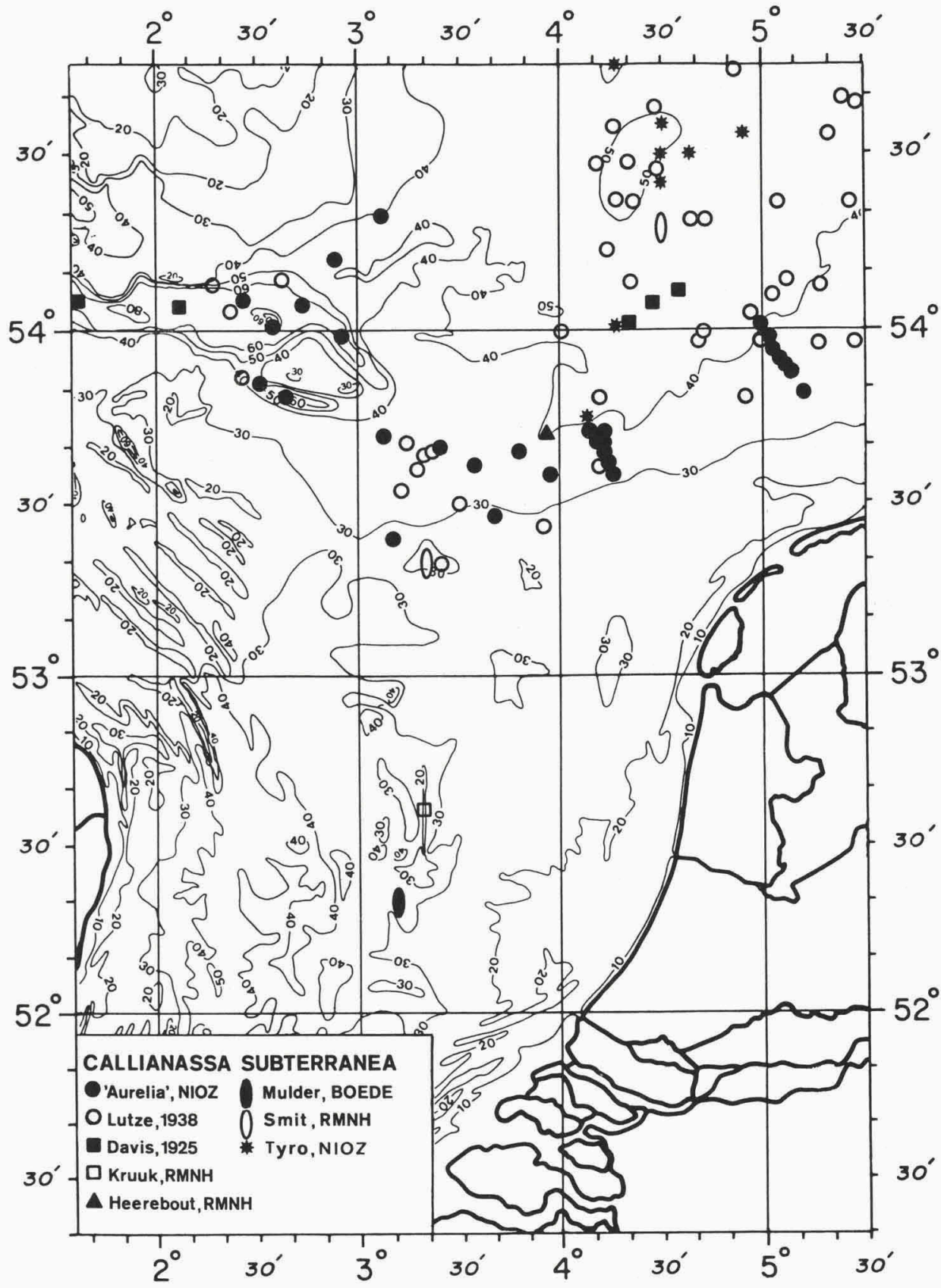

Map 4. Callianassa subterranea in the southern North Sea. 
According to Saint Laurent \& Božić (1972) Callianassa tyrrhena (Petagna) is the most common species of Callianassa along the French coasts of the Atlantic and along the European coasts of the Mediterranean. C. tyrrhena is also reported from the Channel (Saint Malo, Countainville, Roscoff). The species has been recorded twelve times from Dutch waters. As from a few of them no exact localities are known, no map of this species has been made. The species has been found on the following localities: Eierland Ground; Texel Ground; Texel coast; lightship "Noord-Hinder" (51 $32^{\prime} 15^{\prime \prime} \mathrm{N} \mathrm{02}{ }^{\circ} 40^{\prime} 10 " \mathrm{E}$; Holthuis, 1950); 30 miles off IJmuiden, 7.vii. 1950 (RMNH 7381, leg. NIOZ; Holthuis \& Heerebout, 1976); $52^{\circ} 20^{\prime} \mathrm{N} 04^{\circ} 00^{\prime} \mathrm{E}, 19 . v i .1951$ (RMNH 10230 , leg. A. B. Stam); $52^{\circ} 10^{\prime} \mathrm{N}$ $02^{\circ} 15^{\prime} \mathrm{E}, 16 . \mathrm{iv} .1963$ (RMNH 29676, leg. NIOZ); 52 ${ }^{\circ} 11^{\prime} \mathrm{N} 04^{\circ} 21^{\prime} \mathrm{E}$ (nearby the Scheveningen coast), 6/18.ix.1965 (not yet registered, leg. D. Eisma). The collection of the Leiden Museum also holds two specimens from the stomachs of fishes: one without date, from the stomach of a Thornback Ray, Raja clavata Linnaeus, 1758, and one from the stomach of a Smooth Hound, Mustelus mustelus (Linnaeus, 1758), collected on 16.ii.1951; both fishes were caught near the Deep Hole, southern North Sea.

Recently two specimens have been collected in the Southern Bight: 12.ii.1980, $52^{\circ} 19^{\prime} 08^{\prime \prime} \mathrm{N} 03^{\circ} 13^{\prime} 55^{\prime \prime} \mathrm{E}$ and $52^{\circ} 16^{\prime} 29^{\prime \prime} \mathrm{N} \mathrm{03}{ }^{\circ} 32^{\prime} 14^{\prime \prime} \mathrm{E}$, leg. M. Mulder (coll. Boede, Texel).

During the "Aurelia"-cruises C. tyrrhena has not been collected. The two records in June 1972 (Sta. 117 \& 140) in the Oyster Ground (see Van Noort, Van Leeuwen \& Creutzberg, 1979b: 10) most probably refer to C. subterranea, since at the time only Holthuis (1950) and Holthuis \& Heerebout (1976) were consulted. Unfortunately the material of these records got lost.

\section{Genus Upogebia Leach, 1813}

Holthuis (1950) and Holthuis \& Heerebout (1976) mentioned only one species of Upogebia Leach for the Dutch fauna, viz. U. stellata (Montagu, 1808). There are, however, a number of records of $U$. deltaura (Leach, 1816)-especially in the Oyster Ground-that suggests that the latter species is more common in the southern North Sea than the former.

The two species can be identified as follows (after De Morgan, 1910):

1. Orbital margin without spine near eyestalk. Rostrum more or less rounded, strongly pilose. Dactylus of the larger cheliped slightly longer than the fixed finger. Living animal of a uniform plain colour ........... U. deltaura (fig. 8)

- Orbital margin of the carapace with a distinct spine near eyestalk. Rostrum more or less pointed, scarcely pilose. Dactylus of the larger cheliped much longer than the fixed finger. Living animal spotted U. stellata (fig. 9) 

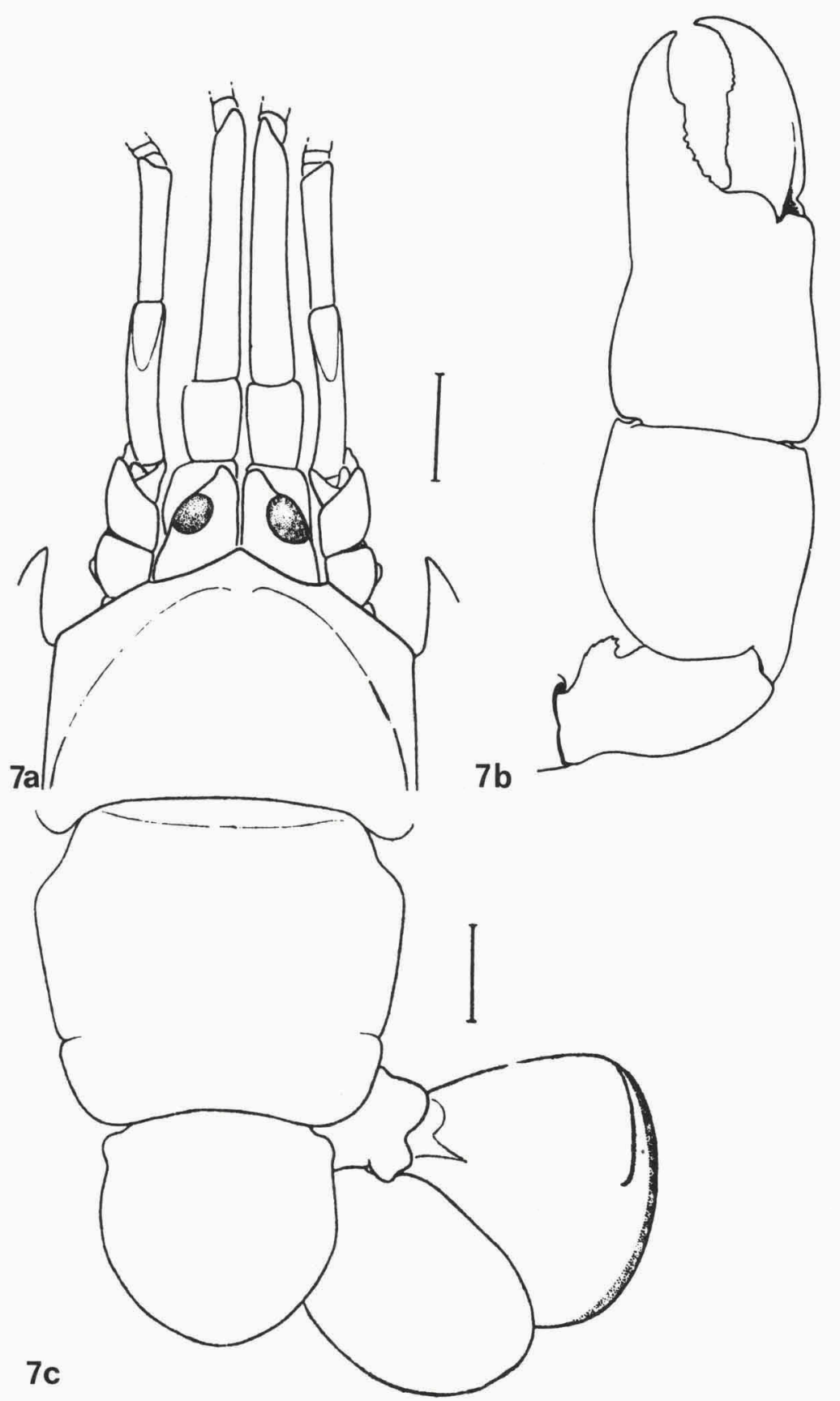

Fig. 7. Callianssa tyrthena. Q , length $32 \mathrm{~mm}$, Morocco (after Saint Laurent \& Božić, 1972). a, frontal region of carapace, showing the eyes; $b$, larger cheliped; $c$, telson. 
Gebia deltura; De Morgan, 1910: 475, fig. 2. Davis, 1925: 40.

Upogebia deltaura; Caspers, 1939: 42, 70. Van Noort \& Creutzberg, 1981: 9.

Upogebia stellata; Van Noort, Van Leeuwen \& Creutzberg, 1979a: 10, 59; 1979b: 10, 58; $1979 \mathrm{~d}: 99$.

Upogebia deltaura (Leach) is known from earlier bottom-fauna studies of the southern North Sea. Davis (1925) collected one specimen in the Oyster Ground, $54^{\circ} 06^{\prime} \mathrm{N} 04^{\circ} 35^{\prime} \mathrm{E}$. According to Caspers (1939) $U$. deltaura is common in the Helgoland Channel.

The collection of the RMNH holds several specimens of $U$. deltaura collected in the southern North Sea (map 5).

During the "Aurelia"-cruises $U$. deltaura was frequently collected, especially in the Oyster Ground, with the Van Veen bottom-sampler as well as with the beam-trawl. In the beginning (April 1972, Sta. 54 \& 55; June 1972, Sta. 117) they were identified as $U$. stellata and have been listed under that name (Van Noort, Van Leeuwen \& Creutzberg, 1979a, b). Re-examination by Dr. L. B. Holthuis, Leiden, however, revealed that most of the specimens belong to $U$. deltaura; only one of these specimens (Sta. 54) could be identified as $U$. stellata (Montagu, 1808) (Van Noort, Van Leeuwen \& Creutzberg, 1979d). The locations where $U$. deltaura has been recorded are summarized in map 5.

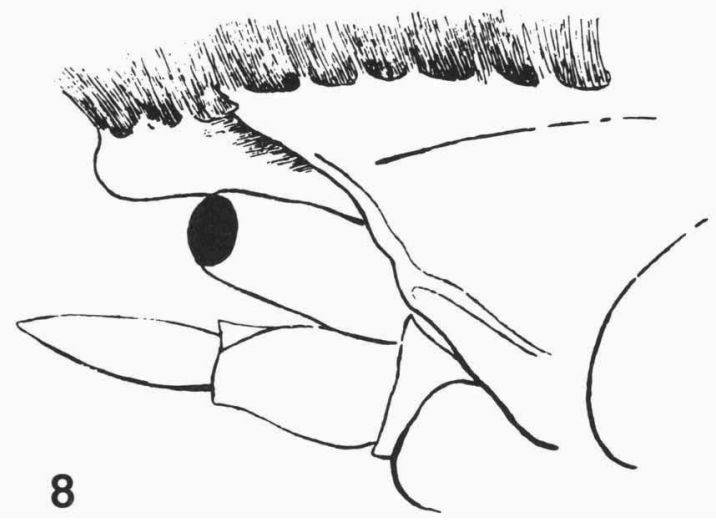

Fig. 8. Upogebia deltaura, length $45 \mathrm{~mm}$, frontal region of carapace (after De Morgan, 1910).

Upogebia stellata (Montagu, 1808)

(fig. 9 ; table 6)

Upogebia stellata; De Morgan, 1910: 475, fig. 1. Holthuis, 1950: 111, fig. 39. Holthuis \& Heerebout, 1976: 17, fig. 64. Van Noort, Van Leeuwen \& Creutzberg, 1979d: 99. Van Noort \& Creutzberg, 1981: 9 .

Upogebia stellata (Montagu) is, apparently, less common than $U$. deltaura in the southern North Sea. According to Holthuis (1950) and Holthuis \& Heerebout 


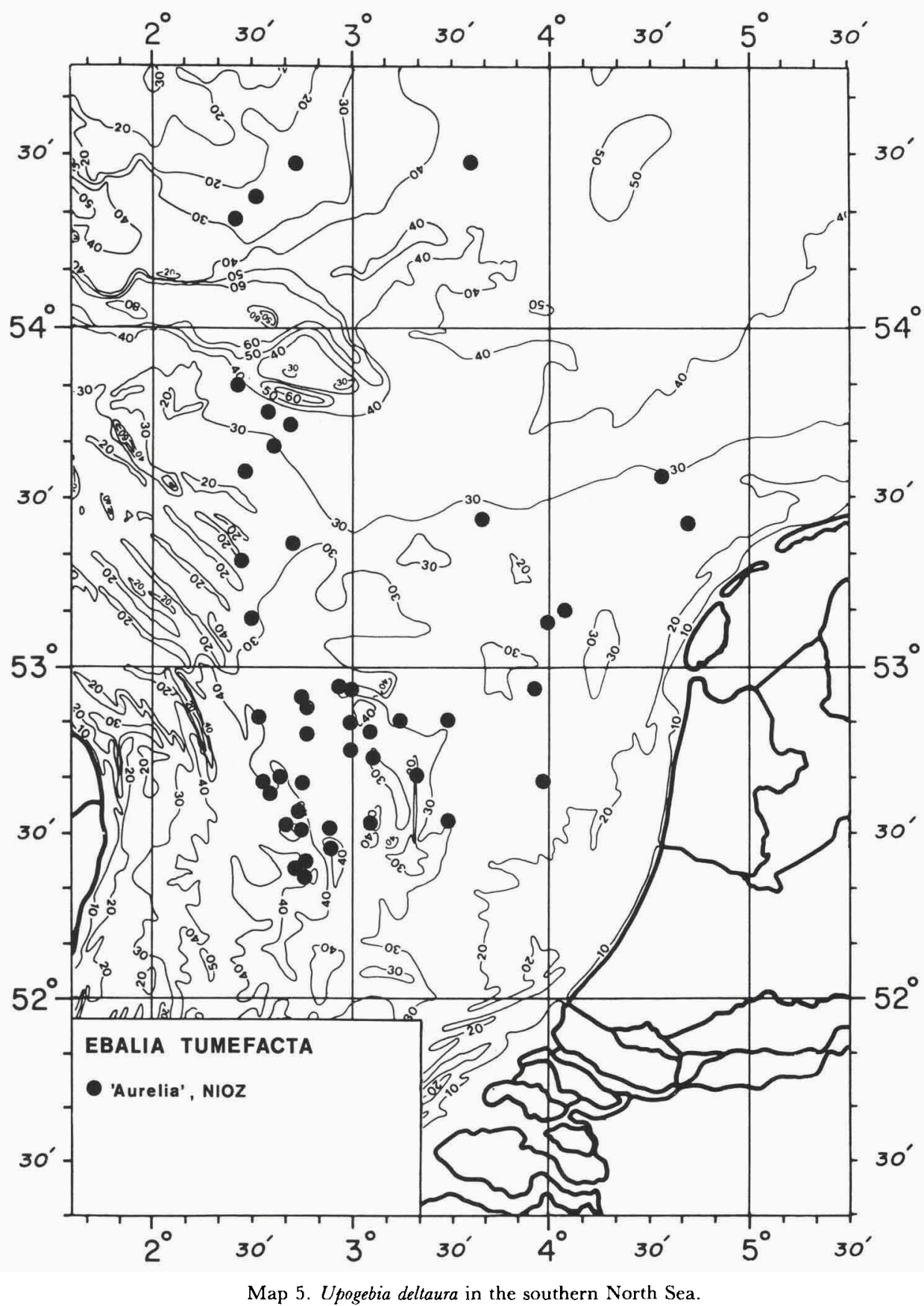


(1976) the species is reported from the neighbourhood of the lightship "NoordHinder" $\left(51^{\circ} 32^{\prime} \mathrm{N} 02^{\circ} 40^{\prime} \mathrm{E}\right)$. The collection of the Leiden Museum holds two other specimens of $U$. stellata collected in the southern North Sea: one collected on 16.iv. 1963 at $52^{\circ} 10^{\prime} \mathrm{N} 02^{\circ} 15^{\prime} \mathrm{E}$ (RMNH 29677, leg. NIOZ), the other collected on $23 . i v .1980$ at $53^{\circ} 36^{\prime} \mathrm{N} 03^{\circ} 45^{\prime} \mathrm{E}$ (leg. P. C. Goudswaard, not yet registered).

During the "Aurelia"-cruises five speciments of the species have been collected, in about the same localities where $U$. deltaura is found (table 6).

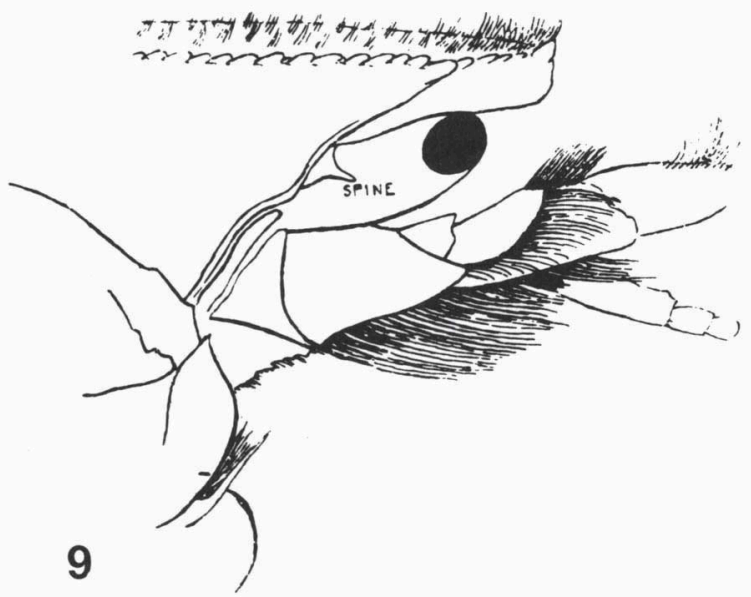

Fig. 9. Upogebia stellaia, length $45 \mathrm{~mm}$, frontal region of carapace (after De Morgan, 1910).

TABLE 6

Upogebia stellata collected during the "Aurelia"-cruises

\begin{tabular}{|c|c|c|c|c|}
\hline Date & locality & station & number & collection \\
\hline 24.iv. 1972 & $53^{\circ} 43^{\prime} \mathrm{N} 04^{\circ} 14^{\prime} \mathrm{E}$ & 54 & 1 & RMNH \\
\hline 29.ix. 1972 & $53^{\circ} 49^{\prime} \mathrm{N} 04^{\circ} 06^{\prime} \mathrm{E}$ & 333 & 1 & NIOZ \\
\hline $6 . x .1975$ & $53^{\circ} 37^{\prime} \mathrm{N} 03^{\circ} 35^{\prime} \mathrm{E}$ & 345 & 1 & RMNH \\
\hline $18 . x \cdot 1977$ & $53^{\circ} 43^{\prime} \mathrm{N} 04^{\circ} 14^{\prime} \mathrm{E}$ & E 91 & 1 & NIOZ \\
\hline $16 . x \cdot 1979$ & $54^{\circ} 12^{\prime} \mathrm{N} 02^{\circ} 54^{\prime} \mathrm{E}$ & BH $18 c$ & 1 & NIOZ \\
\hline $11 . \mathrm{iv} / 22 . \mathrm{iv} .1981$ & $54^{\circ} 30^{\prime} \mathrm{N} 04^{\circ} 21.5^{\prime} \mathrm{E}$ & -- & 1 & NIOZ-TYRO \\
\hline 11.iv/22.iv.1981 & $54^{\circ} 35^{\prime} \mathrm{N} 04^{\circ} 30^{\prime} \mathrm{E}$ & -- & 1 & NIOZ-TYRO \\
\hline
\end{tabular}

\section{ACKNOWLEDgements}

The authors wish to thank Mr. H., Strack, Natuurhistorisch Museum, Rotterdam, for providing material of Atelecyclus rotundatus and Dr. L. B. Holthuis, Rijksmuseum van Natuurlijke Historie, Leiden, for critically reading the manuscript. 


\section{SUMMARY}

The present paper deals with some scarcely known species of Decapoda from which no or only incidental records are known from the southern North Sea. Of a number of them new records are added, but these still remain incidental. This holds true for species like Pandalina brevirostris, Spironiocaris lilljeborgii, Pontophilus spinosus, P. bispinosus, Alphaeus macrocheles, Galathea dispersa, Ebalia iuberosa, Atelecyclus rotundatus, Monodaeus couchii, Callianassa tyrthena and Upogebia stellata. Two of these species, Monodaeus couchii and Alpheus macrocheles were recorded for the first time for the entire North Sea. Four species appeared to be represented by well established populations in the southern North Sea and possibly play a role in the benthic ecosystem. The species in question are: Ebalia tumefacta, E. cranchii, Callianassa subterranea and Upogebia deltaura.

\section{SAmenVatting}

Van de in dit artikel genoemde soorten Decapoda waren tot nu toe geen of slechts incidentele vondsten uit de zuidelijke Noordzee bekend.

Twee soorten, Monodaeus couchii en Alphaeus macrocheles, waren nog niet eerder in de Noordzee gevonden.

In een aantal gevallen werden aanvullende gegevens verkregen, maar bleven deze incidenteel. Het gaat hierbij om Pandalina brevirostris, Spirontocaris lilljeborgii, Pontophilus bispinosus, P. spinosus, Galathea dispersa, Ebalia tuberosa, Atelecyclus rotundatus, Callianassa tyrrhena en Upogebia stellata.

Vier soorten werden in relatief grote dichtheden gevonden. Deze organismen spelen waarschijnlijk een rol in het benthonische ecosysteem. Het betreft hier Ebalia tumefacta, E. cranchii, Callianassa subterranea en Upogebia deltaura.

\section{ReFERENCES}

Caspers, H., 1939. Die Bodenfauna der Helgoländer Tiefen Rinne. - Helgoländer wiss. Meeresunters., 2 (1): 1-112, figs. 1-35, tables 1-22.

Creutzberg, F. H. Postma, 1979. An experimental approach to the distribution of mud in the southern North Sea. - Neth. J. Sea Res., 13 (1): 99-116, figs. 1-7.

Christiansen, M. E., 1969. Decapoda Brachyura. - Mar. Invert. Scand., 2: 1-143, figs. 1-54, maps $1-47$.

Davis, F. M., 1925. Quantitative studies on the fauna of the sea bottom No. 2. - Results of the investigations in the southern North Sea, 1921-24. - Fishery Invest., Lond., (ser. ii) 8 (4): 1-50, figs. 1-2; tables 1-7; apps. 1-5.

De Morgan, W., 1910. On the Species Upogebia stellata and Gebia deltura. - J mar. bio. Ass. U.K., (n. ser.) 8: 475-478, figs. 1-2.

Hacmeier, A., 1925. Vorläufiger Bericht über die vorbereitenden Untersuchungen der Bodenfauna der Deutschen Bucht mit dem Petersen-Bodengreifer. - Ber. dt. wiss. Kommn Meeresforsch., 1: 247-272, tables 1-10.

Heerebout, G. R. 1974. Distribution and ecology of the Decapoda Natantia of the estuarine region of the rivers Rhine, Meuse and Scheldt. - Neth. J. Sea Res., 8 (1): 73-93, figs. 1-11.

Holthuis, L. B., 1950. Decapoda (K IX). A. Natantia, Macrura Reptantia en Stomatopoda $(\mathrm{K} \mathrm{X})$. - Fauna Ned., 15: 1-166, figs. 1-54.

Holthuis, L. B. \& G. R. Heerebout, 1976. De Nederlandse Decapoda (Garnalen, Kreeften, Krabben). - Wet. Meded. K. ned. natuurh. Ver., 111: 1-56. figs. 1-66.

INGLE, R. W., 1980. British crabs: 1-222, figs. 1-111, pls. 1-34. London, Oxford.

LEeUwen, F. VAN, 1975. Verspreiding van verschillende garnalen soorten in de zuidelijke Noordzee gedurende verschillende seizoenen. - Nederlands Instituut voor Onderzoek der Zee, Texel. Publikaties en Verslagen, 1975-8: 1-23, tables i-viii, figs. 1-35.

Leloup, E., 1941. Contributions à l'étude de la faune belge. XI. Les crustacés décapodes brachyoures de la côte belge. - Bull. Mus. r. Hist. nat. Belg., 17 (11): 1-19, 1 map.

Lutze, J., 1938. Ueber Systematik, Entwicklung und Oecologie von Callianassa. - Helgoländer wiss. Meeresunters., 1 (2): 162-199, figs. 1-107, tables i-ii. 
Noort, G. J. van \& F. Creutzberg, 1981. "Aurelia"-cruise reports on the benthic fauna of the southern North Sea. Report 5: trawl survey October-November 1974. - Interne Verslagen Nederlands Instituut voor Onderzoek der Zee, Texel, 1981-1: 1-116.

Noort, G. J. van F. van Leeuwen \& F. Creutzberg, 1979a. "Aurelia"-cruise reports on the benthic fauna of the southern North Sea. Report 1: trawl survey April-May 1972. Interne Verslagen Nederlands Instituut voor Onderzoek der Zee, Texel, 1979-5: 1-104.

- - 1979b. "Aurelia"-cruise reports on the bentic fauna of the southern North Sea. Report 2: trawl survey June-July 1972. - Interne Verslagen Nederlands Instituut voor Onderzoek der Zee, 1979-6: 1-107.

- - 1979c. "Aurelia"-cruise reports on the benthic fauna of the southern North Sea. Report 3: trawl survey October-November 1972. - Interne Verslagen Nederlands Instituut voor Onderzoek der Zee, Texel, 1979-7: 1-115

- - 1979d. "Aurelia"'-cruise reports on the benthic fauna of the southern North Sea. Report 4: trawl survey January-February 1973. - Interne Verslagen Nederlands Instituut voor Onderzoek der Zee, Texel, 1979-8: 1-100.

Saint-Laurent, M. DE \& B. Božlć, 1976. Diagnoses et tableau de détermination des Callianasses de l'Atlantique nord oriental et de Méditerranée (Crustacea, Decapoda, Callianassidae). Thalassia jugosl., 8 (1): 15-40, figs. 1-35.

Smaldon, G., 1979. British Coastal Shrimps and Prawns. - Synopses Br. Fauna, (new ser.) 15: 1-126, figs. $1+51$.

WolfF, W. J. \& A. J. J. SAndeE, 1972. Distribution and ecology of the Decapoda Reptantia of the estuarine area of the rivers Rhine, Meuse and Scheldt. - Neth. J. Sea Res., 5 (2): 197-226, figs. 1-15. 